\title{
East Asian Francophone Writers and Racialised Aesthetics? \\ - Gao Xingjian and Aki Shimazaki
}

This essays explores the connection between aesthetics and the question of race in literary works by francophone writers of East Asian descent, asking on the one hand how race is relevant to understanding literary aesthetics, and on the other, how aesthetics may also transform our perceptions and criticism of racial constructs. Since the 1980s, East Asian francophone writers have formed an important emerging body of literature, seen as "one of the most promising areas of Francophone studies."i This East Asian francophonie includes more than twenty-five writers of Chinese, Japanese, and Korean origins ${ }^{\mathrm{ii}}$ who are shaped by twentieth-century migratory movements and the formation of East Asian diasporas in Europe and North America. As the growing field of criticism on these East Asian writers show, they transform la francophonie beyond the postcolonial and pose questions about interpretive approaches to migrant writers of minority ethnicities.

Nevertheless, the recognition of these East-Asian francophone writers typically involves the simplistic perception that they are exotic spokespeople for their ethnic groups and 'native' cultures who convey specifically Chinese, Japanese, or Korean images and ideas to their Western audience. As Nicholas Harrison observes, writers of minority groups are never read as individuals but always generalised into a "typicality" that reflects their ethnic and cultural group.iii In other words, the non-white Francophone writer is "condemned to dialogue" with her country of "origin".iv This is true of East Asian francophone writers, who, despite falling outside French colonial history, belong to ethnicities and cultures that have been enduring objects of chinoiseriste and japoniste fantasy. Can our critical understanding of these writers be furthered by addressing the question of race? How may we dispute the racialised Frenchlanguage literary market and categorisation of these diverse writers as well as recognise their 
differences from other Francophone and white French writers? This essay addresses these questions by taking as case-studies the Chinese-French writer Gao Xingjian (1940-) and the Japanese-Québecois writer Aki Shimazaki (1954-). Besides being two of the most prolific East Asian francophone writers with continuous output, Gao and Shimazaki form an interesting pair of comparison that can enhance our understanding of theoretical connections between discourses about race, aesthetics, and literary reception. The comparison hinges upon both writers' depreciation of racialised interpretations of their works and insistence on the universality of their themes and aesthetics, aspiring to transcend racial and political identity. These authorial intentions clearly contrast the images of Gao and Shimazaki in the literary market, which raises the question of what the universal means for Gao and Shimazaki, and how it stands within an already racialised literary field? May we think of a relativised universality, and does it provide effective arguments against predisposed perceptions of minority ethnic writers?

East Asian francophone writers pose important questions about what taxonomy should be used to approach them and how French-language literature is racialised. To call writers such as Gao and Shimazaki 'francophone' already carries political and racialising implications. La francophonie is a political and ideological category that conventionally denotes literature from France's ex-colonies, in clear contrast to la littérature franco-française. This division, with its implied racial binary of white French literature and French-language literature produced by peoples of colour, has been strongly challenged by the 2007 manifesto "Pour une littératuremonde en français", which argued that the white "franco-French" canon be subsumed under the francophone. By calling Gao and Shimazaki 'francophone', I agree with the 2007 manifesto on liberating la francophonie from colonial history and resisting the French/Francophone hierarchy. The East Asian francophone writer does not fit the stereotype of the francophone writer as a black writer from a country that was historically colonised by France, for the former 
embodies a "francophonie libre/choisie" in contrast to the latter's "francophonie contrainte".v But the East Asian writer suffers similar processes of exoticisation and racialisation, in more subtle forms of culturalist views that essentialise cultural differences and produce stereotypical images. For example, Gao is pre-dominantly discussed with other diasporic Chinese-French writers and in the context of twentieth-century Chinese history, but seldom discussed with other French and European writers (with an occasional comparison to Beckett, Brecht, and Artaud). Chinese politics is also brought up repeatedly in Gao's interviews, though Gao considers his works written after leaving China as his best.vi Although this understandably has much to do with Gao's Chinese-language writings and experience of Chinese censorship, it still reveals a critical bias towards Gao that insists on his Chineseness despite his French citizenship, French-language works, and strong aesthetic resonances with European and North American avant-gardes. Shimazaki, similarly, is exoticised by book reviewers and critics who see the simplicity of her language as a particularly Japanese trait. E.g. Shimazaki's language is described as "minimaliste", in short "haiku-like" sentences, vii full of 'délicatesse', viii even though Shimazaki has attributed her stylistic minimalism to her use of French rather than Japanese: "En japonais, mes phrases sont plus longues";ix "Le français m'a apporté la clarté et la précision".x These culturalist views are nevertheless submerged forms of racist perception that imply peoples of different cultural heritage are incompatible.

At this conjunction of race and literature stands the question of aesthetics, where lies the tension between understanding aesthetics as universal or racialised. This essay takes into account both Gao's and Shimazaki's evocation of aesthetic universality, but will pose aesthetics as a question in suspense. It explores whether aesthetics provides an autonomous space where a neutral universality is possible, or whether 'aesthetics' - the term and concept that stem from the Greek aisthesis ("sensation", "perception") - is always already a category that carries inherent racial and cultural biases. Thinking about aesthetics in Gao's and Shimazaki's works 
involves, firstly, examining their literary style, thematic concerns, writerly and readerly experience. How the presence or absence of race in their works relates to their aesthetic concerns about literary creation is particularly important here. Simultaneously, we need to question the premises of aesthetic theory that are deeply rooted in Kantian aesthetic "disinterestedness" and Adorno's "functionless" aesthetics as autonomous from society. These notions that separate aesthetics from politics and ethics and support the idea of aesthetic universality are themselves a particular product of European modernity, i.e. culturally and historically contingent. If we consider Chinese and Japanese terms that approximate "aesthetics", we have 審美shenmei and 美學meixue/bigaku (used both in Chinese and Japanese), both of which centre on the notion of beauty (美), - much more abstract than aisthesis, - and the acts of assessing (審) and studying (學). Historically, in China and Japan, beauty and its appreciation and cultivation closely intertwined with moral sensibilities, social class, and gender (especially masculine and feminine styles of writing). This contrasts with European theories about aesthetic autonomy. If aesthetics can be gendered and shaped by culture, then it can be racialised too. By comparativising and racialising aesthetics we may become more aware of any inherent conceptual biases, revise and enrich our understanding of aesthetics. One such conceptual enrichment seems to be found in the 'transcultural'. In recent decades, the term 'transcultural aesthetics' has gained currency and is now frequently used to characterise émigré writers of minority ethnicities like Gao and Shimazaki. Notably, one definition of the transcultural, argued by Patrice Pavis, is that it "creates hybrid forms drawing upon [...] traditions traceable to distinct cultural areas," resulting in a new aesthetic that "transcends particular cultures on behalf of a universality of the human condition."xi The transcultural thus seems to enable aesthetics to break away from ethnocentric and culturally particularist interpretations, asserting the international relevance of migrant and diasporic 
literature. Nonetheless, it implicitly affirms that there are distinct cultural entities, as if cultures have not always been hybrid, changing, and with fluid boundaries. Moreover, the 'transcultural' is typically used for colonial borderlands where hierarchies of power mix and clash, xii and for writers of non-European and non-white heritage who do not fit comfortably into the white Western canon. Gao is repeated described as 'transcultural' (e.g. by Todd Coulter, Claire Conceison, Sy Ren Quah) whereas Kafka, Picasso, and Ionesco are rarely characterised as such. This suggests that the transcultural is analogous to the racially métis, and denotes aesthetics in a less 'pure' form, even though 'pure' aesthetics pertaining to a distinct culture is a fiction. Paradoxically, therefore, 'transcultural' aesthetics encompasses both the cosmopolitan, transnational, universal, and a subtly racialised aesthetics of métissage. Rather than only see the 'transcultural' as suspect to racial and cultural biases, can it also be employed to break down the dichotomy between aesthetics as neutral or racialised? - so that transcultural aesthetics may overflow racial constructs and transform relations between race and literature? These questions will be explored by considering Gao's and Shimazaki's engagements with the race question in their creative writings and critical views, and by assessing their aesthetics of universality within their respective racial and political contexts.

\section{Gao Xingjian}

Gao's writings are linguistically divided between French and Chinese. Since 2000 when he won the Nobel Prize, Gao has increasingly written in French. Significantly, we observe that this linguistic split in Gao's works also correlates with differing degrees of his engagement with the race question. Gao's Chinese writings show his keen awareness of racial identity and explicit championing of minority ethnicities and cultures, whereas his French writings invariably depict characters and themes that are depersonalised, abstract, and apolitical. In more detail, we may briefly consider two Chinese-language works by Gao, translated into French by Noël and 
Liliane Dutrait as La Montagne de l'âme (1995) and Le Livre d'un homme seul (2000). In La Montagne, there are notable references to minority ethnicities in Southern China such as the Qiang (chapter 2), Yi (chapter 21), and Miao (chapter 41). These ethnic groups and their cultures have been, according to Gao (Témoignage, 45-78), marginalised by the Beijing-centric state and Confucian orthodox culture that reinforces Han Chinese ethnic dominance. xiii Through the 'I' persona's journey through these ethnic minority regions, Gao gives voice to underrepresented peoples and cultural aspects in China. In Le Livre, a heavily autobiographical fiction where the narrator, a Chinese man in exile in Hong Kong, reminisces his traumatic memories of the Cultural Revolution, an obvious reference to racial identity and discrimination is the narrator's lover Marguerite, a German-Jew. The Holocaust is evoked multiple times through Marguerite, who absolutely affirms her Jewish identity and urges the narrator to remember his past and denounce totalitarian power : "Elle dit que bien que son père soit allemand, sa mère est juive, [...] elle ne peut se soustraire au souvenir."xiv Gao's pairing of the narrator and Marguerite is all the more meaningful because "the shared identities as diaspora" between them "set up a historical parallel between the Cultural Revolution and the Holocaust, not only due to the atrocities against humanity that occurred during these [events], but even more because of their traumatic effect on the personal psyche."xv Suffering and trauma establish the emotional bind between the narrator and Marguerite, with Marguerite's identity as the crucial "déclencheur" of the narrator's memories. ${ }^{x v i}$

In contrast, Gao's French writings do not engage with the theme of race. These works comprising plays, poems, and critical essays, but never novels - are generally highly abstract and metaphorical. They manifest the hybrid aesthetics that, as Mary Mazzilli observes, hardly contain any culturally or ethnically specific features, earning the epithet of 'transcultural'. xvii For example, the stage settings of Gao's French plays typically indicate no particular historical background, location, or the characters' identities. Characters are generic and indicated as "le 
jeune homme", "la jeune fille", "l'homme" (in La fuite, 1992); "une femme", "une autre femme" (in Au bord de la vie, 1993); or sometimes they are named by their roles: "le somnambule", "le sans-abri", "la prostituée" (in Le somnambule, 1995). Gao's characteristic use of personal pronouns instead of names also conveys the impression of impersonality as well as an address to a general audience: "Elle", "Je", "Vous" (in Ballade nocturne, 2007), and "Tu" in the allegorical poem L'Errance de l'oiseau (2003). This abstract style is seen by Conceison as reflecting the fluidity of categories such as 'nation, language, genre', to which we can also add race and culture.xviii In sum, Gao's French-language works form a remarkable contrast to his earlier Chinese writings, suggesting a deliberate disengagement from questions of racial and cultural identity.

Why this change in Gao's style and themes? And does it relate to his choice of writing in French rather than Chinese? Some explanations can be found in Gao's own views about literature. Firstly, Gao rejects particularist interpretations of his writings because he does not want to be seen as a spokesperson for China, Chinese culture, or Chinese people. For instance, in an interview with Gregory Lee, Gao comments on his Chinese-language works:

"I don't want to emphasize their Chinese background, neither do I want them to be taken as realistic or historical, I'd like them to be read at the level of their common human meaning."

Lee: "That's to say you feel there's a universality to them?"

Gao: "Yes. Of course [...] a good work of literature has to transcend national boundaries."xix

The border-crossing nature of good literature, in Gao's view, renders Chinese particularism impossible in his Chinese-language writings, and in fact would transgress any particularism. But we also observe an implicit opposition Gao draws between being Chinese and being universal, so that Gao's aspiration to the latter means his deliberate distanciation from the 
former. Gao's anxiety to resist being read as a Chinese writer is again manifest in his meeting with Conceison, where Conceison remarks that Gao prefers to use French in interviews, and that "his acquaintances in France are 'Westerners', not Chinese. He does not desire or need Chinese friendships; he does not want to talk about China, which he considers irrelevant to his life and work."xx This suggests that Gao's abstract and de-racialised French works stem partly from his desire to be less Chinese and therefore more universal, besides the liberating effect of writing in French, a language that is dissociated from Gao's unhappy memories of China. Nevertheless, Gao's refusal of Chineseness in favour of universality inadvertently reinforces the Eurocentric view that universality is inherent in the Western canon but not in non-Western literatures. As Jane Hiddleston demonstrates, French colonial discourses have always posited a binary between cultural specificity and universal humanity, presuming that French values are universal while suppressing the difference and particularity of colonised non-white peoples.xxi That "the colonised assert their freedom" and universality "in the very same terms that [they are] conceived by Western civilisation" precisely reaffirms the Franco-centric and colonial version of universality. ${ }^{\text {xii }}$ Likewise, Alain Mabanckou remarks that the francophone African writer is considered closer to universality only when she is less African.xxiii By extension, the Chinese francophone writer can only be either Chinese or universal, whereas the white French writer (e.g. Sartre) can always be both French and universal. Gao's un-Chineseness does not challenge French standards for aesthetic excellence but in effect reaffirms them.

Nevertheless, we need to place Gao's un-Chineseness in the bigger picture of his understanding of aesthetic universality, which is a genuine effort to de-condition the biased conceptual frameworks applied to literature. In Gao's theoretical articulations of 'ne pas avoir de -isme' and 'la littérature froide', he argues that literature and art transcend all political struggles, ideologies, and categories of race, nation, culture. Firstly, "ne pas avoir de -isme" signifies the absence of art's engagement with all isms (including racism, of course), 
"n'avanc[e] aucune proposition politique," and represents no group. ${ }^{\text {xxiv }}$ Literature that embodies 'ne pas avoir de -isme' is its own justification: 'ne pas servir autrui ni être utilisé par autrui' (Témoignage, 12). This is a 'littérature froide' that refuses to be the tool of ideological battles, showing Gao's explicit depreciation of the politicisation of literature. "La littérature n'a rien à voir avec la politique" (Témoignage, 39). The "coldness" of "la littérature froide" is the purified state of literature when everything superfluous to literature itself is pared away: "Cette littérature qui a recouvré ses valeurs intrinsèques, pourquoi ne pas l'appeler 'littérature froide"'(Témoignage, 40-41). In a conversation with the Chinese poet Yang Lian, Gao further asserts: "What we need is a kind of literature that doesn't have any attributes. Such genres as 'pure literature', [...] 'modernism' [...] have no meaning."xxv In this way, "cold" aesthetics fundamentally involves the idea of 'literature without', or simply 'literature'. Only the literariness of literature is literature's raison d'être.

Gao's "cold" aesthetics therefore de-politicises, de-racialises, and de-historises literature. This is equally applicable to Gao's Chinese and French works, i.e. if Gao de-conditions his Chineseness, he also de-conditions his Frenchness and has no desire to exploit his use of the French language as a marker of national identity or cultural distinctness. If Gao avoids the Chinese language because it carries too much baggage and is prone to ethnocentric interpretations, Gao can still use French in an abstract and non-culturally specific way (as in his French works). A writer, after all, has to write in a particular language. But the suggestion here is that we do not need to over-estimate the Frenchness in white "franco-French" literature. As a writer of "la littérature froide", the Chinese francophone writer, black francophone writer, and white French writer are all de-conditioned, becoming simply a 'writer' and equally related to each other. In this sense, literature can become universal and communicate something fundamental to humanity, which is "la difficulté fondamentale d'exister du genre humain," as Gao declares in his Nobel Prize speech (Témoignage, 124). This universality can be understood 
as a common sharedness between all human beings, of which existential vulnerability, - e.g. "difficulté" and "fragilité' (Témoignage, 132) - is the most central aspect. Note that Marguerite and the narrator in Livre are both scarred by oppressive regimes and in exile, implying that nothing other than the embodied experience of suffering has more power in drawing different people together in an empathetic relation. Gao's understanding of universality as a connection relating different people's different experiences together functions like a tertium comparationis, i.e. the respect in which different things are compared. As I argue elsewhere, xxvi the tertium does not need to be an invariant property that exists in the compared elements, it only needs to denote a common ground that is relatable to all compared elements. Human vulnerability can therefore be this common ground that relates to different individuals and their experiences, establishing an affective connection between them. Seen in this light, Gao's universalism relates rather than equates, particularises rather than totalises. It is a fragmented universality that disintegrates "power formation" rather than establishes it.xxvii

In short, both Gao's engagements with and disengagements with the politics of race emerge from a racialised literary field. Gao's "cold" aesthetics is the negative reflection of racialised aesthetics and identity politics, stemming from his refusal to use race to label himself and his works. Although Gao's deliberate dissociation from Chineseness does not seem to challenge European standards of aesthetic universality, when contextualised within Gao's "littérature froide" that de-conditions all ethno- and cultural-centrisms, we understand that Gao endeavours to level the field of aesthetics for Chinese and European literatures alike.

\section{Aki Shimazaki}

Like Gao, Shimazaki evokes universality as the most important interpretive perspective on her own works. In her interview with Linda Amyot, Shimazaki asserts her universal theme is "la 
tragédie humaine".xxviii She addresses big questions in life, injustice for instance: "n'oublions pas que l'injustice est omniprésente, dans n'importe quelle société. C'est un thème universel."xxix The broad relevance of Shimazaki's themes is also confirmed by Gabrielle Parker, who argues for an "interprétation universalisante" of Shimazaki's œuvre.xxx Unlike Gao, however, Shimazaki only writes in French and only fiction. Her novels are invariably about Japan, extremely context-specific, portraying individuals with identity issues that are particular to Japanese society. Her book titles are always Japanese words, e.g. Wasurenagusa ("Forget-menot"), Hotaru ("Fireflies"), and her text strewn with Japanese special terms that are explained in an additional glossary. Shimazaki's works thus manifest a pronounced foreignness to its Francophone readers and seem self-Orientalising, as Musella and Lequin observe, ${ }^{\mathrm{xxx}}$ since Shimazaki fits the stereotype of the migrant minority writer always referring to her ethnic and cultural origins. How does Shimazaki's culturally-specific works co-exist with her claims to universality? Intriguingly, Shimazaki professes: 'Je raconte la vie d'individus, ce qui est universel."xxxii This suggests that Shimazaki sees her own work as both Japanese and universal, which clearly contrasts Gao's conceptual split between Chineseness and universality. But in what way is the individual also universal? As a case-study, we may consider how this question relates to the theme of race in Shimazaki's pentalogy Le Poids des secrets (1999-2004).

Le Poids, comprising five novels: Tsubaki ("Camellia"), Hamaguri ("Clams"), Tsubame ("Swallow"), Wasurenagusa, and Hotaru, narrates a family saga set in the background of twentieth-century Japanese history, with identity and racial discrimination as its central themes. Shimazaki reveals two kinds of racism, each correlated to two historical catastrophes: first, Japanese racism against Koreans, embodied by the Great Kantō earthquake in 1923 which leads to the massacre of Koreans because of false rumours that Koreans poisoned wells and plotted to exploit the crisis; ${ }^{\text {xxxiii }}$ second, American racism against the Japanese, marked by the atomic bombing of Japan in 1945. Shimazaki's explicit treatment of these two racisms with 
different structures - Japanese as oppressors in regard to Koreans but as victims in regard to Americans - suggestively draw them into comparison, making Shimazaki's Western Frenchspeaking readers reflect on racism in Japan and at home. More specifically, Japanese racism against Koreans is not based on prejudices against skin colour and difference in physical appearance, - since the Japanese and Koreans share very similar physical traits, - but on colonial discrimination against non-Japanese East Asian ethnic groups and the belief in pure Japanese blood. In Japanese racial theories, as Yuko Kawai notes, "the idea of Japaneseness" that emerged in modern Japan "created the dominant assumption that the Japanese are a race". xxxiv This contributes to the myth of tan'itsu minzoku, "single-race/ethnic nation", which is fundamental to the construction of Japanese nationality identity. ${ }^{\mathrm{xxv}}$ In this context, anyone who does not have 'pure' Japanese blood is excluded as not fully Japanese. Shimazaki takes issue with this stigma of 'impure' blood through the character Yonhi Kim in Le Poids, an enfant métis born in Japan of a Korean mother and European priest, during Japanese colonial rule of Korea. Yonhi, like many Korean immigrants in Japan, is forced to change her name to Mariko Kanazawa and assume Japanese identity to avoid discrimination. A complete effacement of her ethnic origins - by both society and her own dissimulation - thus occurs, highlighted by Yonhi/Mariko's loss of sense of self and her unidentifiable physical traits: "son visage, qui n'appartenait à aucune race, lui conférait un air mystérieux."xxxvi The absence of racial identity here is not an absence that renders Yonhi/Mariko's origins insignificant, but a presence of absence that makes itself painfully felt. Shimazaki does not offer any hopeful indication of redress of discrimination against Koreans in Japan, as Yonhi/Mariko dies carrying her secret to the grave:

Je n'étais plus capable de lire le coréen. [...] La défaite du Japon et l'indépendance de la Corée n'ont rien changé à l'attitude des Japonais contre les Coréens au Japon. La discrimination est toujours là. [...] Je ne pourrai jamais avouer l'histoire de 
mon origine à mon fils et à sa famille.xxxvii

Shimazaki's portrayal of Yonhi/Mariko is remarkable for its open discussion of and particular sensitivity to Japanese Korea-phobia. This is because "the dominant Japanese view has been that racism is a foreign, not a domestic issue."xxxviii One reason for this obscuration is, Kawai argues, that the Japanese concept of jinshu-shugi, equivalent to the English term 'racism', "refers to racism directed to different jinshu [racial] groups but not to peoples in the same jinshu group;" so discriminatory practices against Koreans and Chinese, i.e. people of the same jinshu [racial] group (though not of Japanese ethnicity) "are often not viewed as racism in Japan."xxxix Shimazaki's portrayal of Yonhi/Mariko's suffering would be particularly politically-charged if she were read in Japan. But because she writes in French and is situated in the North American and European literary market, she is distanced from Japanese audiences and freer to talk about taboos and ideologically obscured issues in Japanese society.

Shimazaki exposes the second type of racism - Americans' discrimination against Japanese and non-European peoples - in another character Yukiko's account of the atomic bombing of Nagasaki. Yukiko survives the bombing, and years later, when her grandson presses her with questions about it, she denounces the underlying violent racism in the catastrophe:

[grandson:] 'Pourquoi ont-ils [i.e. Americans][...] lâché ces deux bombes, grandmère? Les victimes étaient pour la plupart des civils innocents. Plus de deux cent mille personnes ont été tuées en quelques semaines! Quelle est la différence avec l'Holocauste des nazis? [...] Si les bombes atomiques servaient à menacer la Russie ou bien à expérimenter ces nouvelles armes, pourquoi l'ont-ils fait sur le Japon, où il n'y avait rien à détruire? Pourquoi pas sur l'Allemagne?' [Yukiko:] '[...] L'Allemagne avait déjà officiellement renoncé à la guerre. Même dans le cas contraire, les Américains n'auraient pas osé lâcher des bombes 
atomiques au centre de l'Europe. Ils sont des descendants d'Européens, après tout. Pour les Américains, tous les Japonais, civils ou militaires, étaient leurs ennemis, car ils n'étaient pas hakujin."xl

Two things stand out in this conversation: the term hakujin, which is the Japanese expression for "white people", typically denoting white Americans and Europeans, here used by Yukiko to identify white American racism against the Japanese; and the comparison of atomic bombing with the Holocaust - both unique historical events of indescribable violence and human suffering. In regard to the racism of hakujin, according to Yukiko, the second bomb on Nagasaki was an experiment and not necessary for winning the war, but Americans needed to strategically demonstrate their power to Russia and collect data on the effect and power of the bomb. ${ }^{\text {lli }}$ More importantly, Yukiko also believes that because Americans were racist and did not care about experimenting on Japanese lives, i.e. non-white peoples, Americans would rather bomb Japan than Nazi Germany. Although Yukiko's views are not historical reflections and we need to remember that we are hearing a fictional voice, what can they tell us about the importance of racial discourses in wartime and postwar Japan-USA relations, and about Shimazaki's choice to give such views to Yukiko in a French-language novel that targets a mainly white French and Canadian audience?

A brief consideration of historical background shows that racial discourses and conflicts were key aspects in relations between Japan and the Western powers from the interwar period through WWII to postwar decades. The official ideology of the Japanese empire was that Japan would lead Asian peoples' resistance against Western imperialism. This vision was set forth by Yōsuke Matsuoka in his famous speech in 1933 at the League of Nations, where Matsuoka criticised Western attempts to colonise East Asia (particularly China) and established the image of Japan as championing for and protecting peoples of colour in Asia against white European and American colonisers. In practice, however, imperial Japan also inflicted racist violence on 
non-Japanese Asian groups including Koreans, Chinese, and Filipinos. In postwar Japan, the construction of collective mourning and memory of atomic bombing, especially in atomic bomb literature (e.g. Masuji Ibuse's novel Kuroi Ame/Black Rain (1965)), focused on the scale of destruction, catastrophic technological power, and traumatic after-effects of radioactivity. The condemnation of Americans as white racists who cared little about Japanese lives was a relatively minor narrative typically deployed by Japanese right-wing nationalists as an antiAmerican discourse. Compared to other Japanese writers on the memory of atomic bombing, Shimazaki's presentation of the racial narrative is unusually prominent and approximates Japanese nationalist stances. But the very same views, situated in Canada, where Shimazaki is writing in French, take on new political dimensions. Shimazaki obliges her French-speaking readers, mostly white North American and European, to learn about the Japanese perception of atomic bombing as racist violence. Simultaneously, displaced from the Japanese literary and political context, Yukiko's views lose their echo of Japanese nationalist discourses and take on a new confrontational force that probes Shimazaki's Western readers to reflect on their own narratives of the war.

The comparison between atomic bombing and the Holocaust made by Yukiko's grandson in fact frequently occurs in Japanese discourses about war memory and is studied by many historians (e.g. recently by Gordon Fraser). ${ }^{\text {lii }}$ Here, this comparison can be better understood through Shimazaki's connection between universality and individual lives. Rather than subtract from the uniqueness of these two traumatic historical events, Shimazaki suggests that racist violence - though inflicted on different ethnic groups, in different ways and degrees of atrocity - is a commonly-existing problem in all societies which everyone must address. Shimazaki thus reminds her hakujin Francophone audience that the personal and collective tragedies in wartime Japan should not be taken any the less seriously than those in contemporaneous Europe and North America. Simultaneously, this comparison exposes the 
fallacy of hakujin Western peoples' superiority complex that presumes barbarisms only happen elsewhere - e.g. in Japan, in all those non-Western non-white 'backward' cultures - but not at home. Like Gao, Shimazaki's also posits human suffering as the common denominator between atomic bombing and the Holocaust. Suffering becomes a universal relation that connects different individuals despite their ethnic, cultural, and historical differences. Universality here may be understood as the empathetic connectability and comparability between human beings, emerging from comparing two events of suffering and racially-motivated violence. Seen in this light, Shimazaki's statement that "la vie d'individus [...] est universel" precisely makes sense. This is not, therefore, a generalising and neutral universality that denotes a panoramic standard or quality, instead it creates specific connections through literary affect. Shimazaki's evocation of the universal complements rather than contradicts the particular racial violences portrayed in her works.

To conclude, Shimazaki's literary aesthetics - writing in French while keeping distinct Japanese vocabulary and concepts (e.g. koseki, hakujin, zaïnichi) and treating profoundly Japanese historical and cultural experiences - is itself a racialised choice of style that takes on particular critical force for Shimazaki's white Western readers. Those who are initially attracted by the apparent self-Orientalising style of Shimazaki's novels will likely find them biting back with a critique of white self-consciousness. Le Poids thus yields to critical reflections about how the concepts of 'race' and ethnic identity are different in Japan and the West. This stems from the unique position of Shimazaki writing in French about Japan, living in Canada and published jointly by the Québecois press Leméac and Actes Sud in France. A triangular conversation between her works, her Western audience, and the Japanese literary tradition is created. The culturally-specific dimensions of Shimazaki's writings do not contradict their universalising interpretations. 


\section{Aesthetics: racialised, transcultural, and universal?}

Despite wide divergences in style and critical stance between Gao and Shimazaki, they both insist on the importance of universality in their literary themes and aesthetics. For both, this universality is a relation that can "articulate in a common horizon the most disparate modes of being".xliii Nevertheless, Gao's and Shimazaki's claim to universality - also present in other East Asian francophone writers (e.g. Ying Chen, Eun-Ja Kang) - is not neutral and reflects their ethnic and cultural minority standpoint. By claiming that their writing holds universal value, Gao and Shimazaki tell their Western and international audience that their works are not only about China and Japan, but also relevant to non-Chinese and non-Japanese readers. Precisely because East Asian diasporic writers are typically seen as representative of their racial and cultural origins and marketed in Orientalising ways, they are inadvertently condemned to particularisms that imply they have nothing important to say about literature, aesthetics, and humanity beyond East Asia. As Judith Butler says: "What one means by 'the universal' will vary, and the cultural articulation of the term in its various modalities will work against precisely the transcultural status of the claim. [...] the term gains its meaning [...] precisely through the decidedly less-than-universal cultural conditions of its articulation."xliv Both 'universal' and 'transcultural' dimensions of Gao's and Shimazaki's writings are racialised and relativised according to their particular standpoints in the French-language literary field.

From the critic's viewpoint, when race is posed as a question to approach literature, it should not only be applied to minority ethnicity authors but also to majority ethnicity authors (e.g. white American and European authors). Gao's "littérature froide" as "littérature sans" reminds us not to take for granted the Frenchness or Westernness of white Western writers. Relativised universality (for minority writers) can also be a relativising universality (for the majority). Similarly, the métissage of transcultural aesthetics in Gao's and Shimazaki's case as métissage can encompass the cosmopolitan precisely because the latter emerges from the 
for Gao. Instead of a "reconciliatory poetics" that affirms coherence and unity, the transcultural may be formulated as a more conflictory and fragmented aesthetics. ${ }^{x l v}$ This non-conciliatory aesthetics may then transcend superficially coherent categories of 'migrant literature', East Asian diasporic literature, as well as the white Western canon, shedding new light on how they are all hybrid, fractured, and prismatic.

i Karen Thornber, "French Discourse in Chinese, in Chinese Discourse in French," Contemporary French and Francophone Studies, 13:2 (2009): 223.

ii To cite some of the best known: François Cheng, Gao Xingjian, Dai Sijie, Shan Sa, Ying Chen, Aki Shimazaki, Ryoko Sekiguchi, Akira Mizubayashi, Hisashi Okuyama, perhaps Asuka Fujimori (possibly a pseudonym for a writer whose identity is unknown), Eun-Ja Kang, and Ook Chung.

iii Nicholas Harrison, Postcolonial Criticism, (Cambridge: Polity, 2003), 100.

iv Ibid., 104.

v Béatrice Bouvier-Lafitte, "Francophonie chinoise," International Journal of Francophone Studies, 16.3 (2013): $267-$ 8 .

vi Gao in interview with David Der-Wei Wang, https://asiasociety.org/conversation-gao-xingjian [accessed 12 Oct 2018].

vii Linda Amyot, "Aki Shimazaki: Ce qu'on ne peut pas dire," Nuit blanche, no.108 (2007): 46.

viii Lise Schaller, "Un univers japonais sans surpris," https://www.laliberte.ch/news/magazine/page-jeunes/un-universjaponais-sans-surprise-447610 [accessed 2 Oct 2018].

ix Interview with Shimazaki, http://www.lapresse.ca/arts/livres/201511/13/01-4920544-aki-shimazaki-la-methodeshimazaki.php [accessed 26 Sept 2018]

x http://www.lefigaro.fr/livres/2009/01/08/03005-20090108ARTFIG00413-le-francais-langue-d-accueil-de-tous-lesecrivains-du-monde-.php [accessed 30 Sept 2018]

xi Patrice Pavis, "Introduction," in The Intercultural Performance Reader, Pavis, ed. (New York: Routledge, 1996), 68.

xii As in Mary Louise Pratt's Imperial Eyes (London: Routledge, 1992).

xiii The Han are the dominant ethnicity (among the officially recognised 56 ethnicities) in China. When 'Chinese' designates ethnicity it typically means 'Han' Chinese.

xiv Xingjian Gao, Le Livre d'un homme seul, Noël and Liliane Dutrait, trans.(La Tour d'Aigues: L'Aube), 30.

xv Shuyu Kong, "Ma Jian and Gao Xingjian: Intellectual Nomadism and Exilic Consciousness in Sinophone Literature", Canadian Review of Comparative Literature, (2014): 137.

xvi Lena Bisinger, Rencontre interculturelle dans le roman franco-chinois, (Berlin: Logos, 2016), 85.

xvii Mary Mazzilli, Gao Xingjian's Post-Exile Plays, (London/Oxford: Bloomsbury, 2015).

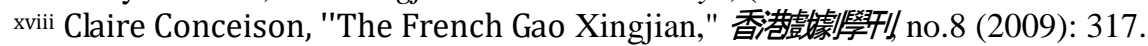

xix Gregory Lee and Noël Dutrait, "Conversations with Gao Xingjian: The First 'Chinese' Winner of the Nobel Prize for Literature," The China Quarterly, no.167 (2001): 742-3.

$\mathrm{xx}$ Conceison (2009): 304.

xxi Jane Hiddleston, Decolonising the Intellectual, (Liverpool: Liverpool University Press, 2014).

xxii Ibid., 151.

xxiii Alain Mabanckou, "Immigration, 'Littérature-Monde', and Universality," Yale French Studies, no.120 (2011): 85.

xxiv Gao, Le Témoignage de la littérature, (Paris: Seuil, 2004): 12.

xxv Gao in Gao and Lian Yang, "The Language of Exile", Index on Censorship, 31(3), (2002): 120.

xxvi Xiaofan Amy Li, "When Do Different Literatures Become Comparable?', in Minding Borders, Adriana X. Jacobs, Matthew Reynolds, et al., eds, (Cambridge: Legenda, 2017).

xxvii Kong (2014): 128.

xxviii

Aki Shimazaki, cited in Amyot, (2007): 45. 
xxix Ibid., 49.

xxx Gabrielle Parker, "Poétique de la distance: deux approches contrastées, Ying Chen et Aki Shimazaki', International Journal of Francophone Studies, 16.3 (2013): 307.

xxxi Sonia Musella, "L'Imaginaire japonais et ses contradictions chez Aki Shimazaki et Asuka Fujimori," Francofonia, no.57(2009); Lucie Lequin, "De la mémoire vive au dire atténué : L'écriture d'Aki Shimazaki," Voix et Images, 31.1 (2005);

xxxii Shimazaki in Amyot (2007): 45-6.

xxxiii The Kantō massacre is still a highly political sensitive topic in Japan and it is unclear to what extent the state was involved, besides mob violence.

xxxiv $\quad$ Yuko Kawai, "Deracialised Race, Obscured Racism," Japanese Studies, 35:1(2015): 24.

${ }^{x x x v}$ Eiji Oguma, 'Nihonjin' no ky okai [The Boundaries of the Japanese], (Shin'y osha, 1998).

xxxvi Shimazaki, Hamaguri, (Leméac/Actes Sud, 2000): 100.

xxxvii Shimazaki, Tsubame, (Leméac/Actes Sud, 2001): 60.

xxxviii Kawai (2015), 26.

xxxix Ibid., 42-43.

xl Shimazaki, Tsubaki, (Leméac/Actes Sud, 1999): 11-13.

xli The ethics and legal aspects of atomic bombing are still debated, but Yukiko's view is not unsupported in some historical studies.

xlii Gordon Fraser, The Quantum Exodus: Jewish Fugitives, the Atomic Bomb, and the Holocaust, (Oxford: Oxford University Press, 2012).

xliii Maxime Cervulle, "The Uses of Universalism. 'Diversity Statistics' and the Race Issue in Contemporary France', European Journal of Cultural Studies, 17(2), (2014): 129.

xliv Judith Butler, "For a careful reading," in Feminist Contentions, S. Benhabib, J. Butler, D. Cornell, eds, (London/New York: Routledge, 1995): 129.

xlv Marie Carrière and Catherine Khordoc, "Revisiting Écriture migrante in Québec," in The Oxford Handbook of Canadian Literature, Cynthia Sugars, ed. (Oxford: Oxford University Press, 2016): 629. 